\title{
Karakteristik Nata De Soya Dari Limbah Cair Tahu dengan Pengaruh Penambahan Ekstrak Jeruk Nipis Dan Gula
}

\author{
Adeline Novianti Putri, Siti Fatimah * \\ Program Studi Teknik Kimia, Fakultas Teknik, Universitas Muhammadiyah Surakarta \\ "corresponding author. : sf120@ums.ac.id \\ DOI : 10.20885/ijca.vol4.iss2.art1
}

\begin{tabular}{l}
\hline ARTIKEL INFO \\
\hline Diterima $\quad: 28$ Mei 2021 \\
Direvisi $\quad: 22$ Juli 2021 \\
Diterbitkan: 18 September 2021 \\
Kata kunci : Limbah cair tahu, Nata \\
de Soya, Acetobacter xylinum, jeruk \\
nipis
\end{tabular}

\section{ABSTRAK}

Banyaknya produksi tahu di Indonesia menyebabkan melimpahnya pula limbah cair tahu. Limbah tersebut jika tidak diolah akan mencemarkan lingkungan sekitar yang nantinya akan menimbulkan dampak yang buruk bagi masyarakat. Salah satu pengolahan limbah cair tahu adalah dengan membuat Nata de Soya. Artikel ini merupakan hasil penelitian mengenai pengolahan limbah cair tahu menjadi Nata de Soya dengan penambahan ekstrak jeruk nipis dan gula dari bakteri Acetobacter xylinum. Selama proses fermentasi, metabolisme Acetobacter xylinum dipengaruhi oleh keasamaan media. Penambahan asam yang digunakan yaitu asam sitrat yang terdapat dalam jeruk nipis. Asam sitrat ini juga digunakan untuk membentuk asam glukonat dengan bantuan bakteri. Selain penambahan ekstrak jeruk nipis, adanya penambahan gula pada pembuatan Nata de Soya akan berpengaruh terhadap karakteristik ketebalan, berat dari Nata de Soya, kadar air, kadar serat, kadar vitamin $\mathrm{C}$ dan rendemennya. Hasil dari penelitian ini didapatkan bahwa Nata de Soya dengan konsentrasi jeruk nipis $10 \mathrm{~mL}$ dan gula 28 (g/L) mempunyai kadar air tertinggi sebesar 98,86\%, pada uji kadar serat hasil tertinggi yaitu pada kadar gula 42 (g/L) dan jeruk nipis $10 \mathrm{~mL}$ dengan perolehan kadar serat sebesar $1,18 \%$, uji kadar vitamin $\mathrm{C}$ tertinggi yaitu pada kadar gula $42(\mathrm{~g} / \mathrm{L})$ dan ekstrak jeruk nipis $30 \mathrm{~mL}$ sebesar 7,40\%. Pada hasil berat nata didapatkan hasil tertinggi yaitu pada ekstrak jeruk nipis $10 \mathrm{ml}$ dan kadar gula 42 $(\mathrm{g} / \mathrm{L})$ sebesar $0,55 \mathrm{~mm}$ dan untuk uji berat nata didapatkan hasil tertinggi sebesar 44,87 cm untuk konsentrasi jeruk nipis $10 \mathrm{~mL}$ dan gula $42(\mathrm{~g} / \mathrm{L})$. Untuk hasil uji rendemen tertinggi diperoleh sebesar $7,40 \%$ pada konsentrasi jeruk nipis $10 \mathrm{~mL}$ dan gula $42(\mathrm{~g} / \mathrm{L})$.

\begin{tabular}{|c|c|}
\hline ARTICLE INFO & $A B S T R A C T$ \\
\hline $\begin{array}{l}\text { Received : } 28 \text { May } 2021 \\
\text { Revised : } 22 \text { July } 2021 \\
\text { Published : } 18 \text { September } 2021 \\
\text { Keywords: Tofu liquid water, Nata } \\
\text { de Soya, Acetobacter xylinum, } \\
\text { lime. }\end{array}$ & $\begin{array}{l}\text { A large amount of tofu production in Indonesia causes an } \\
\text { abundance of tofu liquid waste. If the waste is not processed, it will } \\
\text { pollute the surrounding environment which will have a negative } \\
\text { impact on the community. One of the tofu liquid waste treatments is } \\
\text { to make Nata de Soya. This article discusses the result of research } \\
\text { on the processing of tofu liquid waste into Nata de Soya with the } \\
\text { addition of lime extract and sugar from the bacterium Acetobacter } \\
\text { xylinum. During the fermentation process, the metabolism of } \\
\text { Acetobacter xylinum is affected by the acidity of the medium. The }\end{array}$ \\
\hline
\end{tabular}


addition of the acid used is citric acid contained in lime. Citric acid is also used to form gluconic acid with the help of bacteria. In addition to the addition of lime extract, the addition of sugar in the manufacture of Nata de Soya will affect the characteristics of thickness, weight of Nata de Soya, water content, fiber content, vitamin $C$ content and yield. The results of this study found that Nata de Soya with a concentration of $10 \mathrm{~mL}$ lime and $28 \operatorname{sugar}(\mathrm{g} / \mathrm{L})$ had the highest water content of $98.86 \%$, in the fiber content test the highest results were at a sugar content of $42(\mathrm{~g} / \mathrm{L})$ and $10 \mathrm{~mL}$ lime with fiber content of $1.18 \%$, the highest vitamin C content test was at $42(\mathrm{~g} / \mathrm{L})$ sugar content and $30 \mathrm{~mL}$ lime extract at $7.40 \%$. In the weight of nata, the highest results were obtained, namely $10 \mathrm{ml}$ of lime extract and $42(\mathrm{~g} / \mathrm{L})$ sugar content of $0.55 \mathrm{~mm}$ and for the nata weight test, the highest results were $44.87 \mathrm{~cm}$ for $10 \mathrm{~mL}$ lime and 42 sugar concentrations. $(\mathrm{g} / \mathrm{L})$. For the test results, the highest yield was obtained at $7.40 \%$ at $10 \mathrm{~mL}$ lime concentration and 42 $(g / L)$ sugar.

\section{PENDAHULUAN}

Pembuatan tahu dari bahan dasar kedelai mempunyai hasil lain berupa limbah sebagai produk samping. Adanya limbah tersebut dapat menyebabkan pencemaran lingkungan sehingga perlu adanya penanganan sebagai tindakan meminimalisir pencemaran dengan cara memanfaatkannya. Selain itu adanya limbah dapat menimbulkan dampak bagi kelangsungan hidup masyarakat sekitar yang dekat dengan produksi industri tahu. Berdasarkan data dari kepala Badan Ketahanan Pangan Kementrerian Pertanian (Kementan) Agung Hendriadi pada artikel kompas TV, bahwa produksi kedelai lokal hingga maret 2021 diperkirakan sebanyak 28.754 ton dan akan ditambah stok dari impor kedelai 2,6 juta ton untuk kebutuhan produksi tahu dan tempe.

Badan air yang secara terus menerus mendapatkan limbah cair dari sisa industri akan menyebabkan adanya penurunan kualitas air sungai dan tentunya dapat merugikan kesehatan manusia [1] selain itu, jika semakin meningkatnya jumlah limbah yang terbuang ke perairan maka hal ini kan membahayakan bagi kehidupan makhluk di perairan, karena besarnya kebutuhan oksigen yang digunakan dalam proses penguraian akan meningkat dibandingkan asupan oksigen yang didapat untuk perairan tersebut sehingga kandungan dari oksigen terlarut yang dibutuhkan akan sangat rendah.

Adanya nutrisi penting yang masih terdapat pada whey atau limbah cair tahu sehingga pemanfaatan kembali limbah ini akan sangat berpotensi untuk menghasilkan suatu produk di mana ada $1 \%$ bahan padat, $9 \%$ kandungan protein pada kedelai yang terikut dalam whey, $59 \%$ protein dari susu kedelai yang tidak tergumpal, vitamin B, asam amino, kalsium, dan juga sejumlah glukosa [2], selain itu juga terdapat lemak dan karbohidrat [3] yang memiliki derajat keasaman 4-5 [5]. Melihat hal tersebut salah satu bentuk pemanfaatan whey atau limbah cair tahu ini adalah dengan pembuatan Nata de Soya dimana bahan dasar pembuatannya menggunakan limbah cair tahu.

Keasaman media memengaruhi metabolisme Acetobacter xylinum selama proses fermentasi. Hal tersebut disebabkan sifat permeabel pada sel bakteri dengan ion hidrogen ataupun ion hidroksil, sehingga akan berpengaruh terhadap sitoplasma pada sel bakteri dan juga perubahan pada keasaman media fermentasi. $\mathrm{pH}$ ideal dalam pembuatan proses pembuatan nata berkisar antara $\mathrm{pH} 4-5$. Media fermentasi yang asam dengan penambahan asam sitrat dapat mempengaruhi $\mathrm{pH}$ keasaman media fermentasi selain itu juga digunakan oleh bakteri dalam pembentukan asam glukonat. Pada penelitian ini digunakan asam sitrat yang terdapat dalam buah jeruk nipis[6]. Dimana pada penelitian ini akan diteliti bagaimana pengaruh dari adanya penambahan asam dan juga gula. Selain itu, terdapat beberapa pengujian dari berat, tebal, kadar air, kadar serat, dan juga rendemen.

Pemilihan penambahan ekstrak jeruk nipis dikarenakan terdapat banyak kandungan unsurunsur pada senyawa kimia yang terdapat pada jeruk nipis yang bermanfaat, seperti asam sitrat, kalsium, minyak atsiri, asam amino, geranil asetat, linalin asetat, limonene, sitral, felladren, damar, 
glikosida, fosfor, besi, asam sitrun, lemak, belerang vitamin B1 dan C [7]. Selain itu, kandungan asam sitrat terbanyak sebesar $7 \%$ berada di jeruk nipis [8].

\section{METODE PENELITIAN}

\subsection{Variabel, Alat dan Bahan}

Terdapat tiga variabel pada penelitian ini, yaitu variabel bebas yang diujikan, variabel tergantung dan variabel kontrol dengan kondisi yang sama untuk semua perlakuan. Variabel bebas yaitu pada volume konsentrasi ekstrak jeruk nipis $(10 \mathrm{ml}$ dan $30 \mathrm{ml})$ dan konsentrasi gula $(28 \mathrm{~g} / \mathrm{L}$ dan $42 \mathrm{~g} / \mathrm{L}$ ). Untuk variabel tergantung yaitu berat dan tebal (karakteristik) Nata de Soya, kadar air, kadar serat, kadar vitamin $\mathrm{C}$, dan kadar rendemen. Untuk variabel kontrol yaitu $\mathrm{pH}$, suhu, kelembapan, volume limbah cair tahu, nutrisi.

Alat-alat yang digunakan pada penelitian ini antara lain Aerator, alat pengukur $\mathrm{pH}$, alumunium foil, blender, botol aquades, botol timbang, cawan porselen, corong kaca, corong plastik, desikator, ember/wadah penampung, erlenmeyer, gelas beker, gelas ukur, hot plate, jangka sorong, jerigen, kaca arloji, kaca hisap, karet gelang, kertas koran/jagung, kertas saring, kompor, kondensor, labu ukut, lap, mortar, nampan plastik, neraca analitik, panci, pengaduk, pengaduk kaca, penggaris, pipet tetes, pipet ukur, pisau, saringan, selang, statif, dan toples. Adapun bahan yang digunakan antara lain ZA, starter nata, ekstrak jeruk nipis, gula pasir, dan limbah cair tahu.

\subsection{Prosedur Penelitian}

Penelitian ini akan melakukan fermentasi limbah cair tahu oleh bakteri Acetobacter Xylinum menggunakan variasi konsentrasi ekstrak jeruk nipis dan gula terhadap karakteristik Nata de Soya yang dihasilkan. Ada beberapa tahapan pada pelaksanaan penelitian ini diantaranya:

1. Tahap persiapan

Menyiapkan keperluan alat dan bahan yang dibutuhkan sebagai instrument dalam penelitian.

2. Tahap penyiapan ekstrak jeruk nipis

Buah jeruk nipis yang berkualitas baik dan tidak cacat yang selanjutnya akan digunakan dalam penelitian ini. Kemudian buah jeruk nipis ini dicuci bersih dan dikupas untuk di buang kulitnya lalu dipotong dan diperas, setelah itu disaring untuk diambil ekstraknya.

3. Tahap pembuatan media

Limbah cair tahu (whey) diukur menggunakan gelas ukur sebanyak $500 \mathrm{ml}$ (untuk masing-masing variasi), disaring menggunakan saringan lalu dimasukkan ke dalam panci. Kemudian dididihkan sampai 10 menit di atas kompor, ketika didihkan ditambahkan ZA sebanyak $4 \mathrm{~g} / \mathrm{L}$ lalu diaduk menggunakan pengaduk. Kemudian didinginkan hingga suhu dibawah $40^{\circ} \mathrm{C}$ atau sampai hangat suam-suam kuku. Setelah itu ditambah gula pasir sesuai variasi kadar gula (28 g/L dan $42 \mathrm{~g} / \mathrm{L})$ dan ditambahkan ekstrak -jeruk nipis sesuai variasi (10 $\mathrm{ml}, 30 \mathrm{ml}$ ). Setelah dingin, $\mathrm{pH}$ diukur dengan menggunakan alat pengukur $\mathrm{pH}$, Acetobacter xylinum cocok hidup di $\mathrm{pH} 4$, selanjutnya cairan dimasukkan ke dalam nampan plastik yang sudah bersih dan steril. Kemudian nampan di tutup dengan kertas koran steril dan penutup dikencangkan dengan karet gelang, ditunggu sampai dingin (pada suhu kamar).

4. Tahap inokulasi

Media whey tahu yang sudah dingin, ditambahkan starter dengan konsentrasi $50 \mathrm{~mL}$ untuk setiap nampan. Selanjutnya nampan plastik ditutup kembali dengan kertas koran dan dikencangkan dengan karet gelang. Nampan dijaga kestabilannya, tidak boleh bergerak atau tergoyang.

5. Tahap inkubasi

Proses inkubasi (Proses fermentasi) dilakukan pada suhu ruang $(28-31)^{\circ} \mathrm{C}$, dan dilakukan selama 10 hari, pada $\mathrm{pH}$ yang dijaga konstan.

6. Tahap karakterisasi

Pada setiap perlakuan di analisis beratnya dengan menggunakan neraca analitik dan untuk tebalnya diukur dengan menggunakan jangka sorong. Setelah itu sampel di uji kadar rendemen, di uji kadar air dengan menggunakan metode gravimetri, lalu uji kadar vitamin c dengan metode iodometri, serta di uji kadar serat dengan metode gravimetri. Pada kadar serat yaitu adanya residu dari sampel yang di dalamnya terdapat selulosa dengan sedikit lignin dan pentosan yang 
dianalisis setelah diasamkan dan dibasakan dengan larutan asam (asam sulfat) dan basa (natrium hidroksida) panas.

\section{Diagram Cara Kerja}

Gambar 1 menunjukan diagram alir pada proses pembuatan Nata de Soya dengan tambahan ekstrak jeruk nipis dan gula.

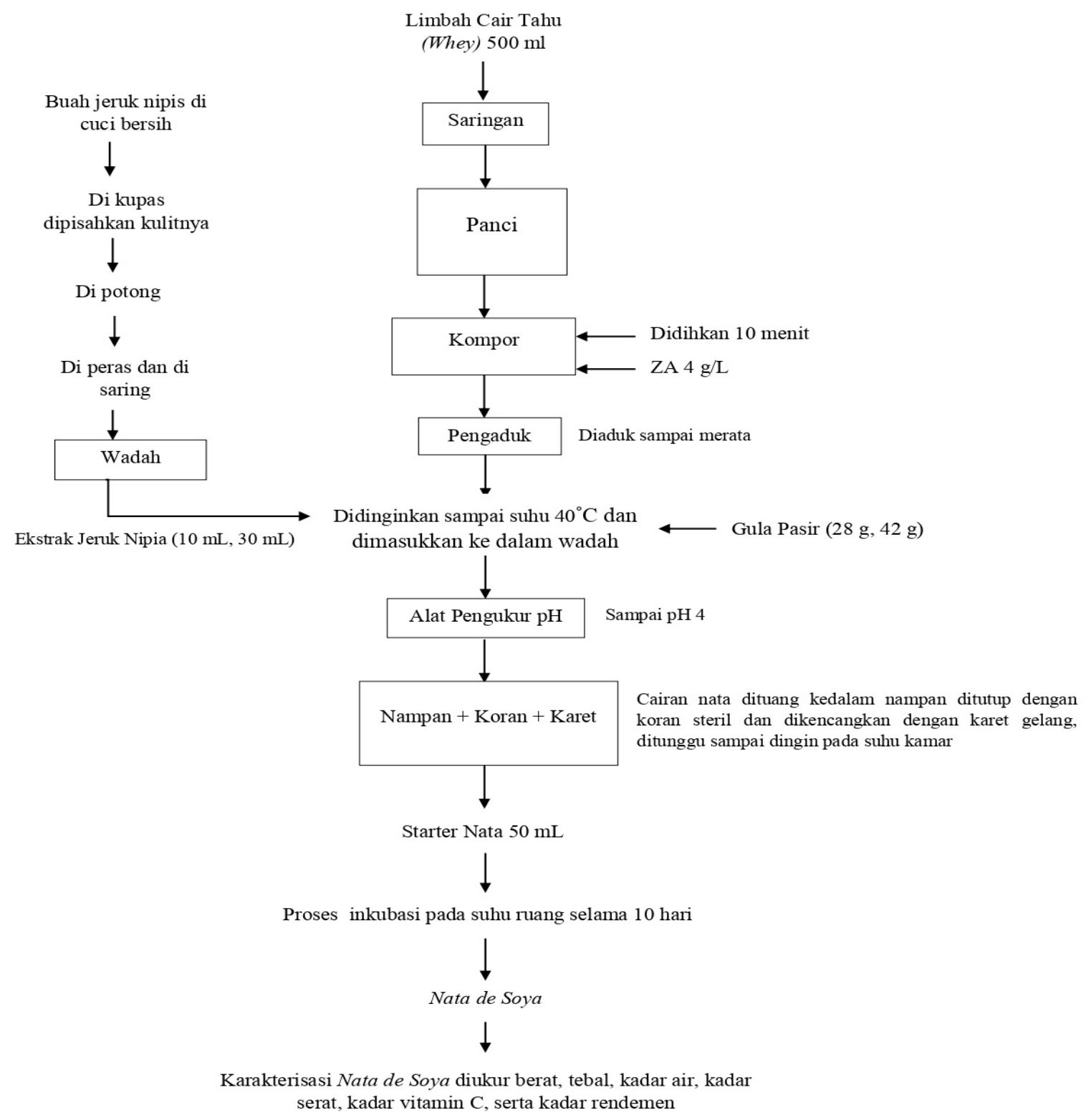

Gambar 1. Diagram Alir Cara Kerja Pembuatan Nata de Soya 


\section{HASIL DAN PEMBAHASAN}

\subsection{Uji Kadar Air}

Tabel 1 menunjukan hasil pengujian kandungan kadar air pada Nata de Soya dengan penambahan ekstrak jeruk nipis dan gula._Hasil penelitian yang telah dilakukan didapatkan hasil kadar air berkisar $94,68 \%$ sampai 98,86\%. Berdasarkan hasil data yang diperoleh maka dapat dibuat grafik hubungan antara kadar gula, konsentrasi ekstrak jeruk nipis dan kadar air, seperti yang ditunjukkan pada Gambar 2.

TABEL I. Nilai Rerata Kadar Air dalam Sampel Nata de Soya.

\begin{tabular}{cccc}
\hline Sampel & $\begin{array}{c}\text { Rerata Kadar Air } \\
(\mathbf{\%})\end{array}$ & $\begin{array}{c}\text { Konsentrasi Ekstrak } \\
(\mathbf{m L} / \mathbf{L})\end{array}$ & Konsentrasi Gula (g) \\
\hline 1 & 94,68 & 10 & 42 \\
2 & 96,10 & 30 & 42 \\
3 & 95,04 & 10 & 28 \\
4 & 98,86 & 30 & 28 \\
\hline
\end{tabular}

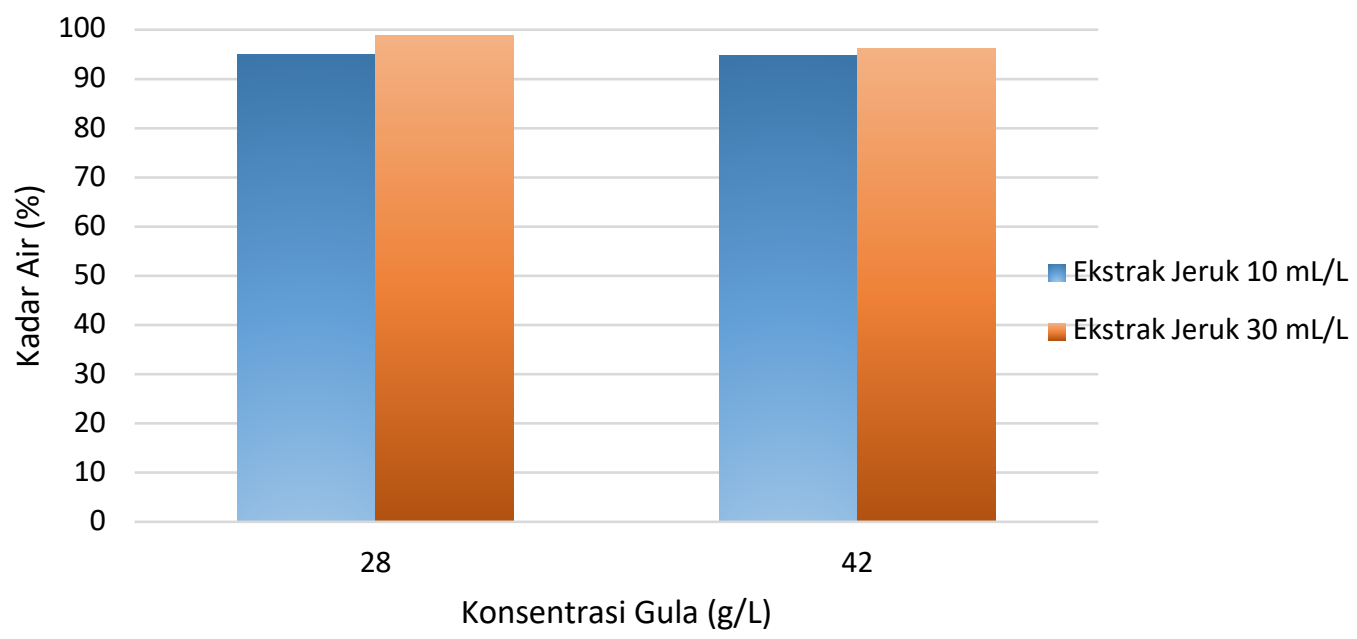

Gambar 2. Grafik kadar Air yang Terdapat dalam Nata de Soya

Berdasarkan Gambar 2 menunjukkan hasil untuk kadar air yang diperoleh pada variasi sampel Nata de Soya. Sebagian besar komponen dalam nata merupakan air karena produk pangan ini dibuat dalam media cair. Kurang kuatnya ikatan antar selulosa sehingga mengikat lebih banyak air yang terikat pada saat pelikel nata terbentuk. Sehingga produk nata mengandung banyak air (Tamimi, dkk., 2015). Berdasarkan grafik (Gambar 2.) menunjukkan bahwa kadar air paling tinggi yaitu pada konsentrasi jeruk nipis sebesar $30 \mathrm{ml}$ dan gula $28(\mathrm{~g} / \mathrm{L})$ sebesar $98,86 \%$, sedangkan kadar air terendah terdapat pada konsentrasi jeruk nipis $10 \mathrm{ml}$ dan gula $42(\mathrm{~g} / \mathrm{L})$ sebesar 94,68. Hal tersebut menunjukkan bahwa semakin rendah kadar gula yang ditambahkan akan mempengaruhi kadar air dari nata. Untuk perlakuan penambahan ekstrak jeruk nipis, meningkatnya jumlah kadar air pada Nata de Soya sejalan dengan meningkatnya konsentrasi pada ekstrak jeruk nipis. Konsentrasi ekstrak jeruk nipis $30 \mathrm{ml}$ menghasilkan nilai kadar air tertinggi. Hal ini dipengaruhi oleh $\mathrm{pH}$ di mana media pada proses fermentasi dengan kondisi yang terlalu asam ( $\mathrm{pH}$ sangat rendah) ini menyebabkan lemahnya ikatan pada selulosa, sehingga air mudah terperangkap karena selulosa yang terbentuk masih bercelah. Terperangkapnya air dengan jumlah yang banyak mengakibatkan kadar air pada Nata de Soya semakin lebih tinggi. Ikatan antar selulosa yang kurang kuat mengakibatkan banyaknya air yang terperangkap. Lambatnya pembentukan selulosa disebabkan karena media fermentasi yang terlalu asam dan adanya kenaikan yang tinggi pada tekanan osmosis sehingga mengakibatkan sel Acetobacter xylinum mudah mengalami lisis dimana hal ini memengaruhi terhadap terbentuknya selulosa yang tidak optimal. 


\subsection{Uji Kadar Serat}

Dari hasil percobaan diperoleh hasil kadar serat berkisar 1,061\% sampai 1,18\%. Berdasarkan pengambilan data dari hasil pengujian kemudian dibuat grafik hubungan kadar gula, konsentrasi ekstrak jeruk nipis dan kadar serat seperti terlihat pada Gambar 3.

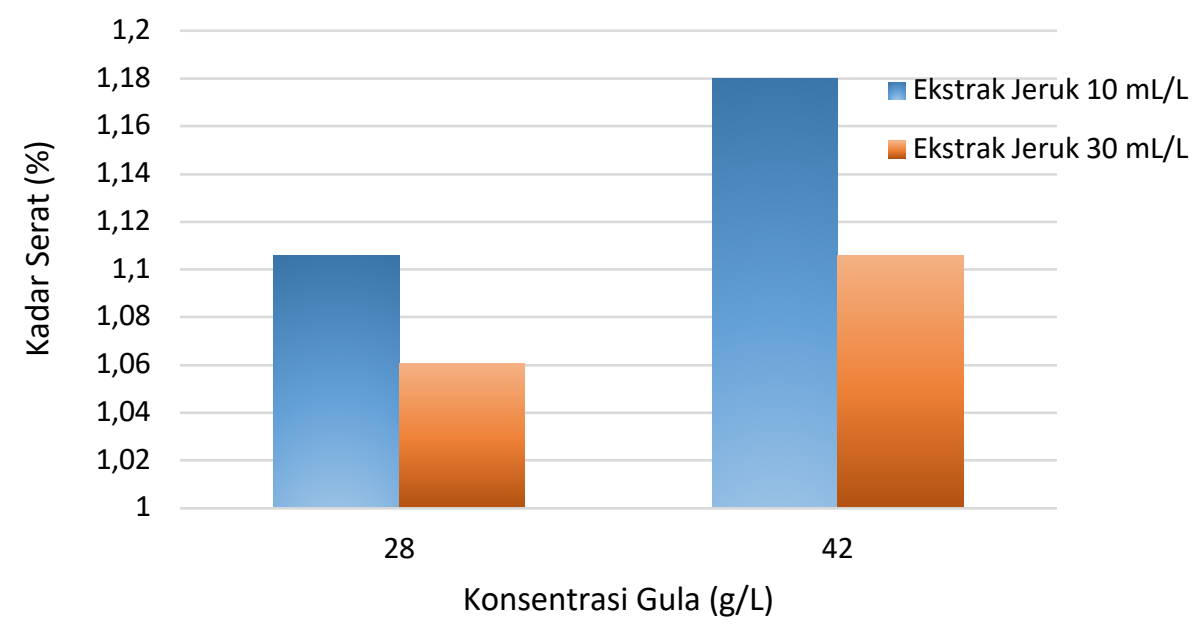

Gambar 3. Grafik kadar Serat yang Terdapat dalam Nata de Soya

Produk nata merupakan hasil olahan pangan fermentasi oleh bakteri Acetobacter xylinum. Dengan adanya bantuan bakteri Acetobacter xylinum tersebut menghasilkan suatu lapisan tipis yang terapung diatasnya. Hasil perubahan ekstraseluler dimana sukrosa yang terdapat di dalam gula menjadi selulosa ini membentuk lapisan tipis, sehingga sel-sel bakteri akan mudah terperangkap pada fiber selulosa dan terbentuknya partikel yang tebal hasil dari fiber selulosa tersebut. Berdasarkan Gambar 3 diperoleh hasil kadar serat paling tinggi yaitu pada variasi kadar gula $42(\mathrm{~g} / \mathrm{L})$ dan ekstrak jeruk nipis $10 \mathrm{ml}$ dengan perolehan kadar serat sebesar 1,18\%, sedangkan untuk kadar serat terendah yaitu pada variasi kadar gula $28(\mathrm{~g} / \mathrm{L})$ dan ekstrak jeruk nipis $30 \mathrm{ml}$ sebesar 1,061\%. Dari data tersebut menunjukkan bahwa hasil analisa kadar serat mengalami peningkatan seiring dengan penambahan kadar gula. hal ini terjadi karena seiring dengan peningkatan kadar gula hingga mencapai optimum menyebabkan kadar sukrosa juga tinggi dimana sumber nutrisi yaitu karbon yang dibutuhkan dalam mengubah sebagian dari glukosa menjadi selulosa oleh Acetobacter xylinum adalah kadar sukrosa yang tinggi. Ketebalan nata yang dipengaruhi oleh banyaknya gula (sukrosa) dapat diubah oleh bakteri Acetobacter xylinum menjadi selulosa sehingga terbentuknya serat akan semakin tinggi. Hasil dari adanya perombakan gula pada proses fermentasi dengan bantuan Acetobacter xylinum akan membentuk serat kasar. Adanya peningkatan yang dihasilkan oleh Acetobacter xylinum pada jumlah lapisan-lapisan selulosa (Serat) ini terjadi karena adanya penambahan gula (Sukrosa). Glukosa yang terdapat dalam larutan gula yang digabungkan dengan asam lemak oleh bakteri acetobacter xylinum sehingga pada membran sel terbentuk prekursor. Dari prekursor inilah yang dikeluarkan bersamaan dengan enzim yang akan mempolimerisasikan glukosan diluar sel menjadi selulosa.

Peningkatan penambahan kadar gula pada proses pembuatan Nata de Soya menunjukkan hasil yang peningkatan signifikan namun itu tidak terjadi dengan peningkatan penambahan ekstrak jeruk nipis, dimana semakin meningkatnya penambahan ekstrak jeruk nipis maka kadar serat yang didapat justru semakin rendah. Hal ini dipengaruhi dengan banyak sedikitnya selulosa yang terbentuk. Semakin tinggi kadar konsentrasi ekstrak jeruk nipis yang ditambahkan, maka akan semakin rendah pula kadar serat yang dihasilkan oleh Nata de Soya. Acetobacter xylinum menjadi terhambat pertumbuhannya jika kondisi media fermentasi ini terlalu asam, sehingga serat-serat yang dihasilkan lebih rendah sebagai akibat dari pembentukan selulosa yang tidak optimal. Pertumbuhan bakteri Acetobacter xylinum pada media fermentasi yaitu dengan pengoptimalan $\mathrm{pH}$ dapat meningkatkan kadar selulosa dan kadar serat nata yang terbentuk dari aktivitas bakteri yang membentuk sel-sel 
baru. Sedangkan pada $\mathrm{pH}$ media fermentasi yang kadar asam nya tinggi (terlalu asam) akan kurang baik jika digunakan untuk pertumbuhan dan perkembangan bakteri Acetobacter xylinum.

\subsection{Uji kadar Vitamin C}

Kadar vitamin C pada Nata de Soya yang dihasilkan pada penelitian ini menunjukkan kenaikan seiring dengan adanya penambahan konsentrasi ekstrak jeruk nipis dan gula. Hal ini seperti ditunjukkan pada Gambar 4.

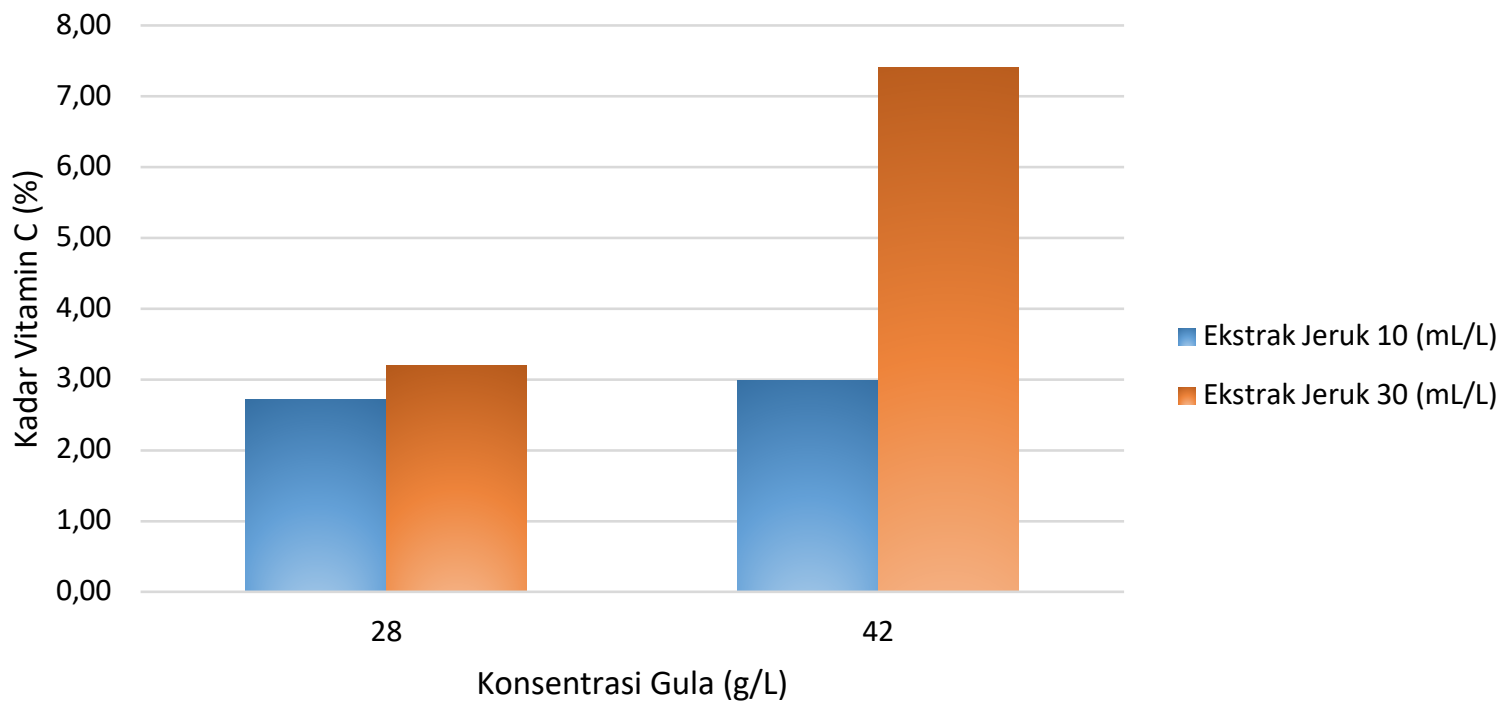

Gambar 4. Kadar Vitamin C pada nata terhadap penambahan konsentrasi ekstrak jeruk nipis dan kadar gula

Gambar 4 menunjukkan bahwa penambahan konsentrasi ekstrak jeruk nipis dan gula memberikan pengaruh terhadap kadar vitamin C Nata de Soya. Terlihat dari hasil kadar Vitamin C tertinggi yaitu pada penambahan ekstrak jeruk nipis $30 \mathrm{ml}$ dan gula $42(\mathrm{~g} / \mathrm{L})$ sebesar $7,40 \%$, sedangkan untuk kadar vitamin $\mathrm{C}$ terendah yaitu pada penambahan ekstrak jeruk nipis $10 \mathrm{ml}$ dan gula $28(\mathrm{~g} / \mathrm{L})$ sebesar $2,72 \%$. Hasil tersebut menunjukkan kecenderungan bahwa penambahan ekstrak jeruk nipis yang ditambahkan maka akan semakin banyak kadar vitamin $\mathrm{C}$ yang larut dalam air, sehingga kadar air berbanding lurus dengan persen kadar vitamin $\mathrm{C}$ yang larut dalam air. Vitamin $\mathrm{C}$ bersifat larut dalam air [12], adanya penambahan konsentrasi ekstrak jeruk nipis memberikan perbandingan yang cukup besar pada terlarutnya vitamin C dalam Nata de Soya.

\subsection{Tebal Nata de Soya}

Penambahan sumber karbon dengan kadar gula dilakukan untuk tercapainya optimalisasi pertumbuhan pada bakteri Acetobacter xylinum. Kondisi yang mempengaruhi keberlangsungan hidup bakteri yaitu bergantung pada kondisi lingkungan seperti komposisi pada $\mathrm{pH}$, media, oksigen terlarut, dan juga sumber karbon. Pada pertumbuhan bakteri Acetobacter xylinum ada batasan kemampuan bakteri ini mampu bertahan hidup yaitu pada $\mathrm{pH}$ tertentu untuk dapat beraktifitas dan melangsungkan hidupya. Hal ini dikarenakan selulosa mengalami polimerisasi glukosa oleh bakteri Acetobacter xylinum dapat terjadi pada kisaran pH 5-7 [11]. Jika merujuk pada Gambar 5 dapat dilihat hasil untuk ketebalan nata yang diperoleh optimum dihasilkan dari kondisi $\mathrm{pH}$ pada kisaran 5-7 yaitu pada $\mathrm{pH}$ asam, adanya penambahan ekstrak jeruk nipis membuat semakin optimalnya media pembuatan nata. Jika dilihat dari data pada grafik (Gambar 5.) hasil tertinggi untuk tingkat ketebalan nata diperoleh pada penambahan ekstrak jeruk nipis $10 \mathrm{ml}$ dan kadar gula $42(\mathrm{~g} / \mathrm{L})$ sebesar $0,55 \mathrm{~mm}$, sedangkan untuk hasil terendah untuk tingkat ketebalan nata diperoleh pada penambahan ekstrak jeruk nipis $30 \mathrm{ml}$ dan kadar gula $28(\mathrm{~g} / \mathrm{L})$ sebesar $0,50 \mathrm{~mm}$. Dari data tersebut menujukkan bahwa konsentrasi penambahan ekstrak jeruk nipis memengaruhi dengan penambahan $10 \mathrm{ml}$ ekstrak jeruk nipis yang paling optimal. Selain itu, ketebalan nata yang mempengaruhi yaitu bergantung pada penambahan gula yang terlihat dengan penambahan kadar gula $42(\mathrm{~g} / \mathrm{L})$ yang mendapatkan 
hasil ketebalan tertinggi. Berikut merupakan foto dari nata de soya yang dihasilkan. Gambar 6(a) dan (b) menunjukan nata de soya dengan ketebalan 0,50-055 mm.

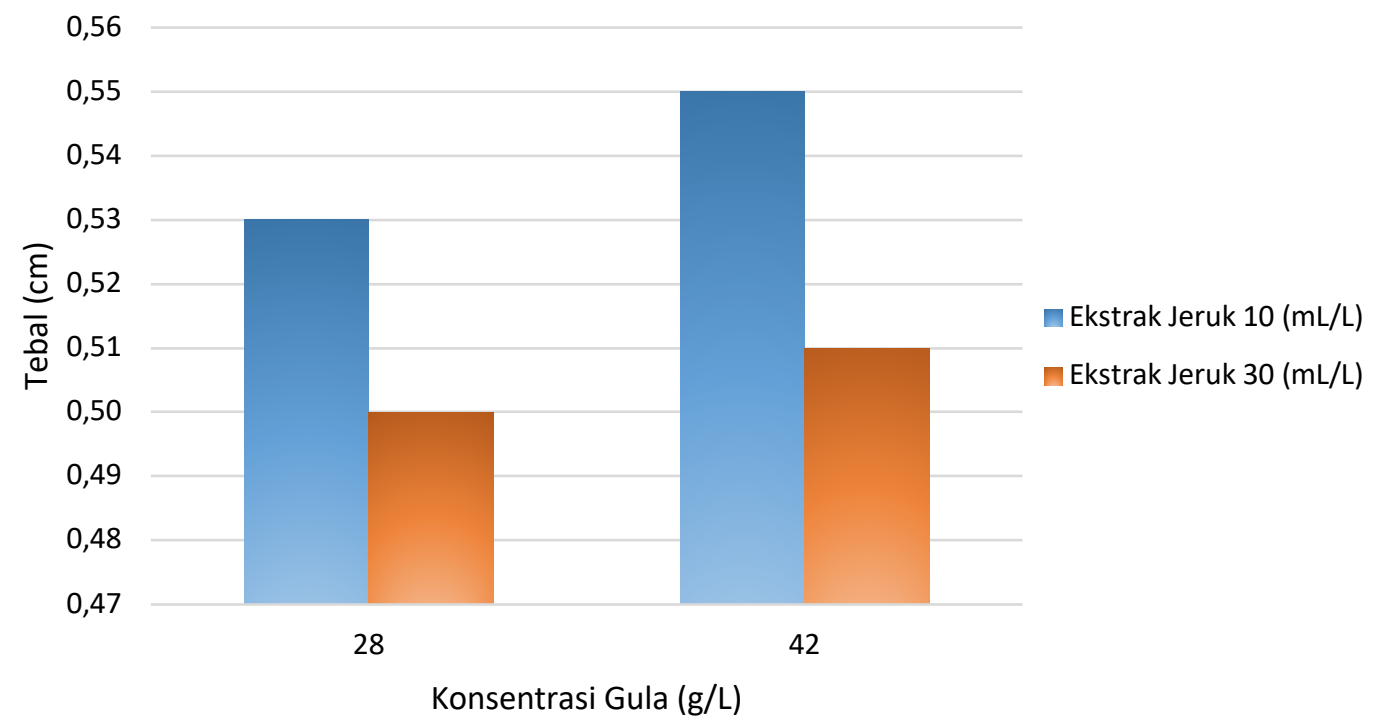

Gambar 5. Ketebalan nata terhadap penambahan konsentrasi ekstrak jeruk nipis dan kadar gula
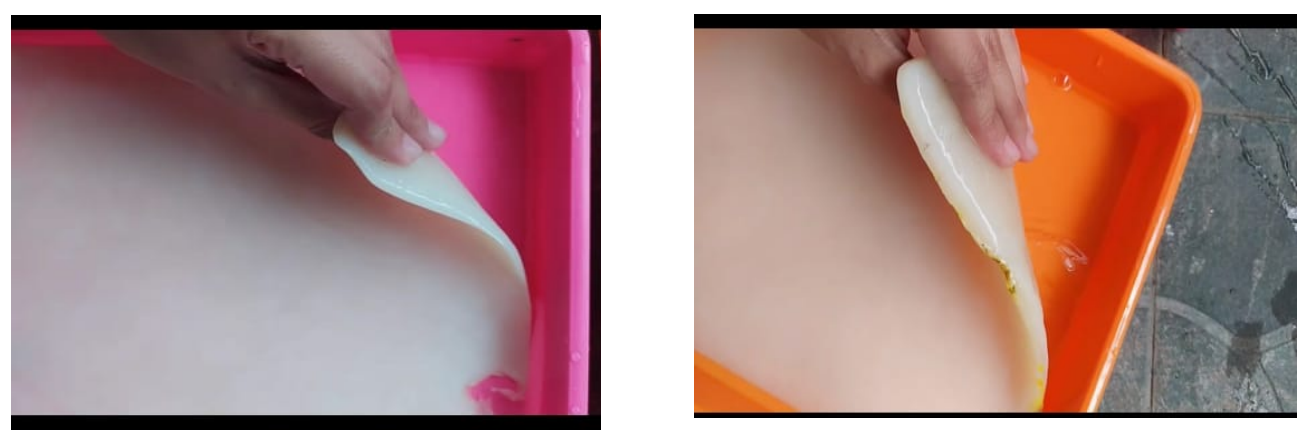

Gambar 6. (a) Nata de Soya dengan ketebala 0,50 mm dan (b) 0,55 mm

\subsection{Berat Nata de Soya}

Berat nata berbanding lurus dengan ketebalan nata itu sendiri. Menurut Putri et al (2021) [13], berat nata dipengaruhi dengan ketebalan dari nata, semakin berat nata maka akan semakin tebal juga. Hasil dari pengujian berat nata terlihat pada Gambar 7. Hasil tersebut menunjukkan hasil berat tertinggi yaitu pada penambahan gula $42(\mathrm{~g} / \mathrm{L})$ dan ekstrak jeruk nipis $10 \mathrm{ml}$ sebesar $44,87 \mathrm{~cm}$ sedangkan hasil berat terendah yaitu pada penambahan gula $28(\mathrm{~g} / \mathrm{L})$ dan ekstrak jeruk nipis $30 \mathrm{ml}$ sebesar 24,36 (g/L). Dari data tersebut di dapat suatu hasil bahwa berat nata berbanding lurus (atau sama) dengan ketebalan dari nata itu sendiri. Jika melihat dari data hasil pengukuran ketebalan nata sebelumnya didapatkan hasil bahwa ketebalan nata tertinggi yaitu pada penambahan gula $42(\mathrm{~g} / \mathrm{L})$, dmana hasil ini sesuai dengan hasil yang diperoleh untuk pengujian berat nata yaitu pada penambahan gula $42 \mathrm{~g} / \mathrm{L})$ merupakan berat tertinggi. Pada penelitian Hardianti dan Wahyudiati (2019) [14], dijelaskan bahwa semakin rendah berat nata maka semakin tinggi pula berat gula yang dibutuhkan. Gula berfungsi sebagai sumber karbon (sumber energi). Sumber karbon bisa menggunakan glukosa, sukrosa maupun maltosa. Hal ini berkaitan dengan adanya sintesa selulosa oleh aktivitas bakteri Acetobacter xylinum sehingga menghasilkan nata dengan ikatan selulosa yang kuat. 


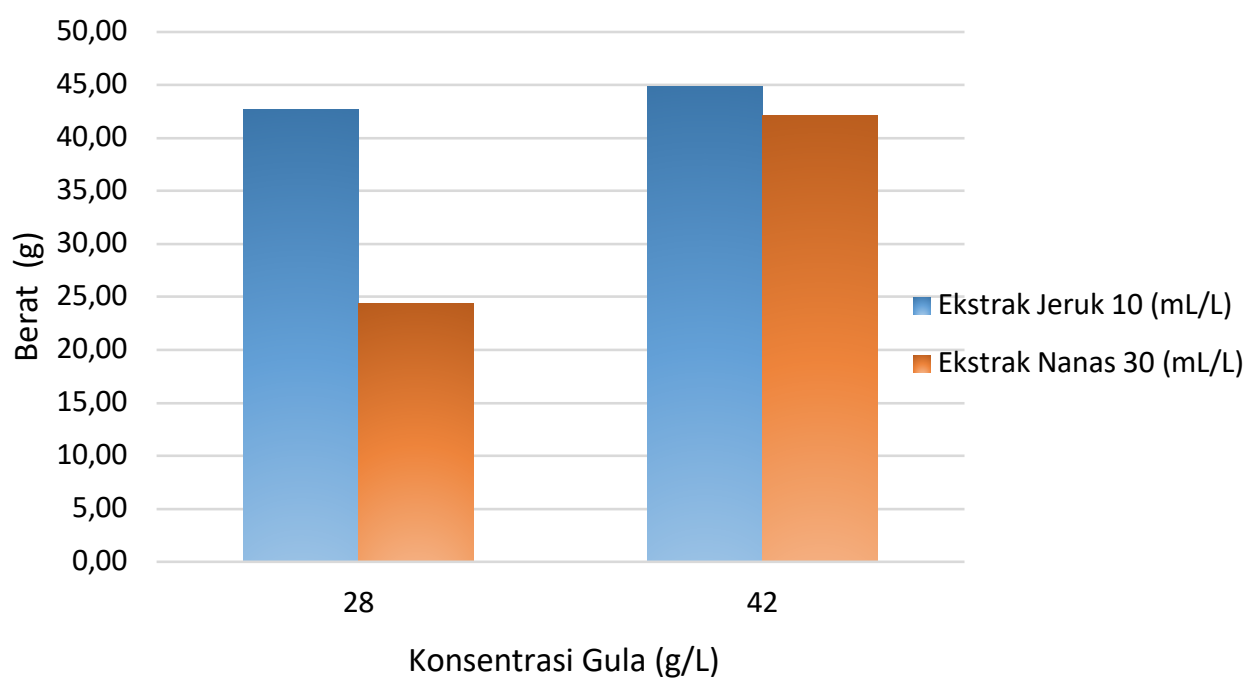

Gambar 7. Grafik berat Nata de Soya terhadap penambahan ekstrak jeruk nipis dan kadar gula

\subsection{Rendemen}

Uji rendemen yang dihasilkan dari penelitian terdahulu berkisar antara 7,7\% sampai $14,4 \%$. Hasil dari penelitian ini menjukkan bahwa hasil rerata rendemen diperoleh berkisar antara 3,98\% hingga 7,40\%. Dari data yang tersebut maka dibuat grafik untuk menujukkan hubungan konsentrasi ekstrak jeruk nipis, kadar gula, dan rendemen, berikut yang ditunjukkan pada Gambar 8.

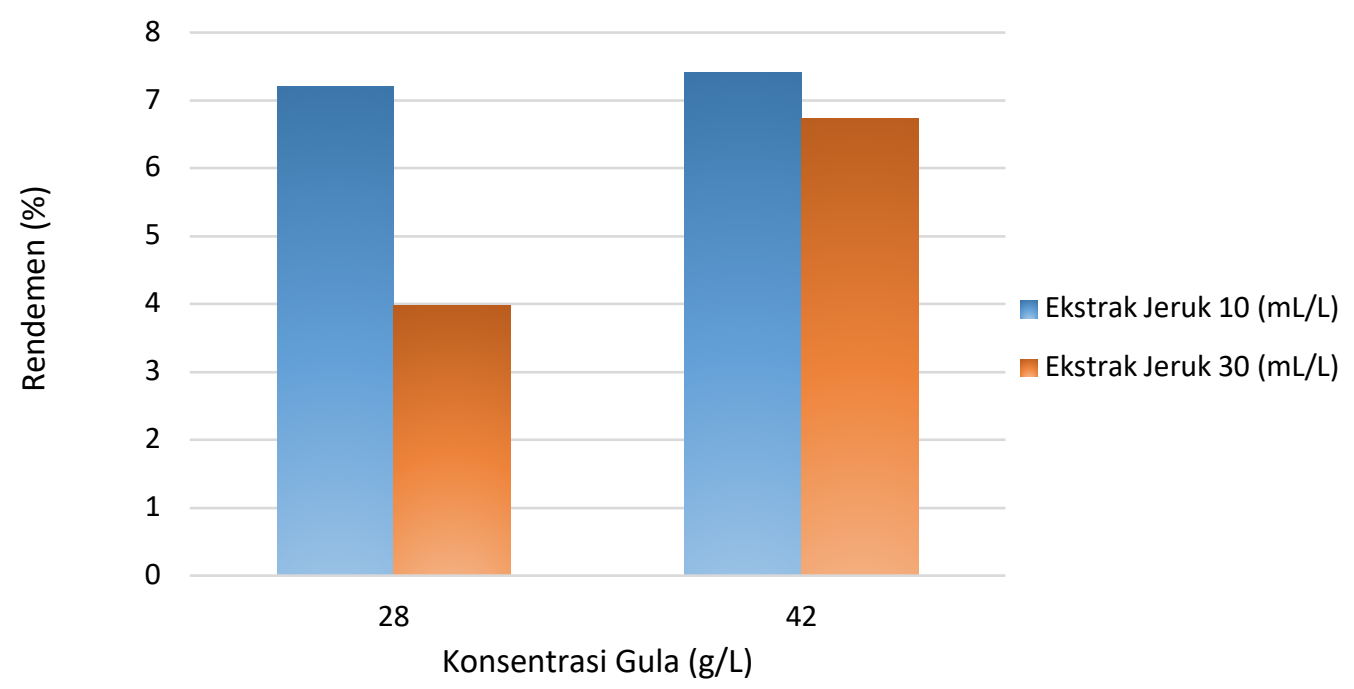

Gambar 8. Nilai Rendemen Pada Nata de Soya

Berdasarkan Gambar 8 menujukkan nilai dari rendemen semakin meningkat seiring dengan bertambahnya konsentrasi kadar gula dan menurunnya penambahan konsetrasi ekstrak jeruk nipis. Hasil rendemen tertinggi yaitu pada penambahan kadar gula $42(\mathrm{~g} / \mathrm{L})$ dan penambahan ekstrak jeruk nipis $10 \mathrm{ml}$ sebesar 7,40\% sedangkan hasil rendemen terendah yaitu pada penambahan kadar gula $28(\mathrm{~g} / \mathrm{L})$ dan penambahan ekstrak jeruk nipis $30 \mathrm{ml}$ sebesar 3,98\%. Adanya peningkatan $\mathrm{pH}$ pada media fermentasi dengan penambahan ekstrak jeruk nipis yang semakin meningkat membuat rendemen yang dihasilkan menurun. Hal ini berbanding terbalik dengan penambahan kadar gula, semakin bertambahnya kadar gula maka semakin meningkatnya nilai rendemen yang dihasilkan. Pengaruh dari tinggi dan rendahnya rendemen yang didapat yaitu dari ketebelan Nata de Soya itu 
sendiri sehingga mengakibatkan semakin tinggi pula selulosa yang terbenrtuk. Menurut Tamiti dan Hendrawan (2015) [9,] aktivitas bakteri Acetobacter xylinum sehingga membentuk selulosa yaitu dengan cara mengubah gula yang terbentuk menjadi menyerupai bentuk gel pada saat proses fermentasi pada permukaan cairan. Pada penelitian sebelumnya juga menunjukkan hasil bahwa semakin meningkatkanya $\mathrm{pH}$ atau semakin bertambahnya penambahan ekstrak jeruk nipis maka hasil rendemen yang dihasilkan semakin berkurang, dimana hasil rendemen tertinggi di peroleh 205,33 untuk penambahan ekstrak jeruk nipis $1 \%$ dan rendemen terendah di peroleh $58,00 \%$ untuk penambahan ekstrak jeruk nipis 5\%. Hasil tersebut sama jika dibandingkan dengan hasil uji dari yang dilakukan oleh peneliti pada penelitian ini dimana peningkatan penambahan ekstrak jeruk nipis berbanding terbalik dengan hasil rendemen yang didapat [6].

\section{KESIMPULAN}

Berdasarkan hasil penelitian yang telah dilakukan mengenai karakteristik Nata de Soya dari limbah cair tahu dengan pengaruh penambahan ekstrak jeruk nipis dan gula maka dapat disimpulkan bahwa hasil uji kadar air diperoleh Semakin rendah kadar gula yang ditambahkan akan mempengaruhi kadar air dari nata, dan semakin meningkatnya konsentrasi ekstrak jeruk nipis maka meningkat pula jumlah kadar air nya. Untuk kadar air tertinggi sebesar 98,86\% dengan konsetrasi ekstrak jeruk nipis $10 \mathrm{~mL}$ dan gula $28(\mathrm{~g} / \mathrm{L})$. Hasil uji kadar serat diperoleh kadar serat mengalami peningkatan seiring dengan penambahan kadar gula. Namun, peningkatan penambahan ekstrak jeruk nipis berbanding terbalik dengan kadar serat yang diperoleh. Untuk kadar serat tertinggi yaitu sebesar $1,18 \%$ dengan gula $42(\mathrm{~g} / \mathrm{L})$ dan konsentrasi ekstrak jeruk nipis $10 \mathrm{~mL}$. Hasil uji kadar vitamin C didapatkan peningkatan konsentrasi ekstrak jeruk nipis yang ditambahkan berpengaruh terhadap kadar vitamin $\mathrm{C}$ yang terkandung didalamnya, dengan perolehan hasil sebesar 7,40\% pada kadar gula 42 (g/L) dam jeruk nipis $30 \mathrm{~mL}$. Karakteristik Nata de Soya pengujian berat Nata de Soya berbanding lurus dengan ketebalan nata. Pada ketebalan nata faktor yang paling berpengaruh yaitu pada penambahan gula, namun pada penambahan ekstrak jeruk nipis tidak begitu terlihat namun ada kondisi optimum kisaran 5-7. Hasil tertinggi tebal nata yaitu $0,55 \mathrm{~mm}$ dan berat nata sebesar 44,87 $\mathrm{cm}$ dengan kadar gula $42(\mathrm{~g} / \mathrm{L})$ dan ekstrak jeruk nipis $10 \mathrm{~mL}$. Hasil rendemen didapatkan yaitu pada Semakin bertambahnya kadar ekstrak jeruk nipis yang ditambahkan maka semakin menurun hasil rendemen yang didapat, namun ini berbanding terbalik dengan penambahan kadar gula, semakin bertambahnya kadar gula semakin meningkatnya nilai rendemen yang dihasilkan. Perolehan hasil rendemen yaitu sebesar 7,40\% dengan gula $42(\mathrm{~g} / \mathrm{L})$ dan ekstrak jeruk nipis $10 \mathrm{~mL}$.

\section{Daftar Pustaka}

[1] W. \& S. Sutiyani, S., "Pemanfaat. Limbah Cair Ind. Tahu Menjadi Nata Soya dan Kecap Berdasarkan Perbandingan Nilai Ekon. Produksi. Tek. Pertanian", 470 - 8383, 2002.

[2] A. Shurtleft, W \& Aoyogi, B. "Tofu Food Mankind", Autum Press. Kanagara, 1975

[3] P. Nurhassan, "Penanganan Air Limbah Pabrik Tahu", Yayasan Bina Karya Lestari (Bintari). Semarang, 1991.

[4] H. Nurhayati, "Dasar-Dasar Ilmu Tanah", Univ. Lampung. Lampung, 1986

[5] N. Rossiana, "Uji Toksisitas Limbah Tahu Sumedang terhadap Reproduksi Dephina carinata King. Lap. penelitian". Fak. Mat. dan Ilmu Pengetah. Alam Univ. Padjajaran. Bandung, 2006

[6] F. Aini, S., \& Nur. "Penambahan Ekstrak Jeruk Nipis Dan Konsentrasi Inokulum Terhadap Karakteristik Nata De Soya Dari Limbah Cair Industri Tahu Kabupaten Klaten”, vol. 4, no. 2, pp. 133-142, 2019.

[7] S. W. Lauma, D. Pangemanan, .B. S. P. Hutagalung. "Uji Ef. Perasan Air Jeruk Nipis (Citrus aurantifolia S) Terhadap Pertumbuhan Bakteri Staphylococcus aureus Secara Vitro". PHARMACON J. Ilm. Farm. 4(4), 2015.

[8] K. Khotimah, K. "Pengaruh Ekstrak Jeruk Nipis (Citrus aurantifolia) dan Metod. Pengolah. pada Kualitas Daging Broiler", Biotechnol. Cent. UMM, Malang.

[9] A. Tamimi, S. Hs, and Y. Hendrawan. "Pengaruh Penambahan Sukrosa Dan Urea Terhadap 
karakteristik Nata de soya Asam jeruk nipis", Bioproses Komod.Trop., vol. 3, no. 1, pp. 6-7, 2015

[10] S. Nurhayati. "Kajian Pengaruh Kadar Gula Dan Lama Fermentasi Terhadap Kualitas Nata De Soya", J. Mat. Sains dan Teknol., vol. 7, no. 1, pp. 40-47, 2006

[11] H. M. Rizal, M. P. Dewi, and S. Abdullah. "Pengaruh Penambahan Gula, Asam Asetat dan Waktu Fermentasi Terhadap Kualitas Nata De Corn", J. Tek. Kim., vol. 19, no. 1, pp. 34-39, 2013.

[12] M. Muzaifa, Y. M. Lubis, and M. Arifullah. "Kajian Pembuatan Infused Water dari Buah Kurma (Phoenix dactylifera) dengan Penambahan Jeruk Nipis (Citrus aurantiifolia)", J. Teknol. dan Ind. Pertan. Indones., vol. 11, no. 2, pp. 84-89, 2006

[13] S. N. Y. Putri, W. F. Syaharani, C. V. B. Utami, D. R. Safitri, N. Arum, Z. S. Prihastari, A. R. Sari, A.R. "Pengaruh Mikroorganisme, Bahan Baku, Dan Waktu Inkubasi Pada Karakter Nata : Review The Effect Of Microorganism, Raw Materials , And Incubation Time On The Characteristic of Nata" : vol. 14, no. 1, pp. 62-74, 2021

[14] B. D. Hardianti and D. Wahyudiati. "Pengaruh Penambahan Jenis Gula Terhadap Berat dan Tebal Nata de Soya The effect of adding sugar to the weight and thickness of Nata de Soya,: vol. 2, 2019

\footnotetext{
Jurnal IJCA is licensed under aÂ Creative Commons Attribution ShareAlike 4.0
} 